\title{
Pengaruh Tata Kelola Perusahaan dan Pertumbuhan Penjualan Terhadap Pajak Agresif Perusahaan Sektor Manufaktur yang Terdaftar di Bursa Efek Indonesia
}

\author{
Syamsidar ${ }^{1^{*}}$, Emmi Suryani Nasution ${ }^{2}$, Rizki Munazar ${ }^{3}$ \\ 1,2,3 Program Studi S1 Akuntansi, Fakultas Ekonomi, Universitas \\ Muhammadiyah Aceh, Kota Banda Aceh, Provinsi Aceh, Indonesia
}

\begin{abstract}
Abstrak. Penelitian ini bertujuan untuk. menguji pengaruh tata kelola perusahaan dan pertumbuban penjualan terhadap pajak agresif perusahaan. Penelitian ini dilakukan pada perusabaan sektor manufaktur yang terdaftar di Bursa Efek Indonesia tabun 2017-2019. Penelitian ini memasukan semua populasi 111 menjadi pengamatan penelitian. Data yang dipakai adalah data panel seimbang, kemudian dianalisis denagan metode Panel Least Squares (PLS) dan dengan uji Common Effect Models (CEM). Hasil penelitian ini menemukan bahwa tata kelola perusahaan dan pertumbuhan penjualan berpengaruh menurunkan pajak agresif, namun tidak signifikan.
\end{abstract}

Kata kunci: Tata Kelola Perusahaan; Pertumbuhan Penjualan; Pajak Agresif.

Abstract. This study aims to examine the effect of corporate governance and sales growth on corporate tax aggressiveness. This research was conducted on manufacturing sector companies listed on the Indonesia Stock Exchange in 2017-2019. This study included all 111 populations as research observations. The data used is balanced panel data, then analyzed using the Panel Least Squares (PLS) method and the Common Effect Models (CEM) test. The results of this study found that corporate governance and sales growth have an effect on reducing tax aggressiveness, but not significantly.

Keywords: Corporate Governance; Sales Growth; Tax Aggressive. 


\section{Pendahuluan}

Pajak adalah salah sumber pendanaan untuk negara. Namun, bagi perusahaan, pajak dipandang sebagai beban yang akan mengurangi laba perusahaan. Bagi pejabat perpajakan, penerimaan pajak yang besar akan mencerminkan usaha yang telah dilakukan, namun bagi perusahaan adakalanya bertolak belakang. Perusahaaan menginginkan pembayaran pajak seminimal mungkin (Atwood, Drake, Myers, \& Myers, 2012).

Upaya minimalisasi pajak yang umumnya disebut dengan tax planning. Ini merupakan celah pada perencanaan pajak yang tidak melanggar hukum. Dengan kata lain ini disebut dengan pajak agresif (Kurniasih, Sulardi, \& Suranta, 2017). Hal ini mencerminkan upaya dari perusahaan dengan cara yang legal untuk merencanakan pajak yang efisien.

Negara sudah mengatur dengan jelas bagaimana tata cara perpajakan bagi perusahaan. Negara juga telah mengatur agar perusahaan tidak mencari celah untuk menghindari pembayaran pajak. Hal ini demi pemasukan untuk negara (Multazam, 2018). Hal ini diatur sedemikian rupa untuk mengantisipasi berbedanya pandangan atas peraturan perapajakan yang dikeluarkan oleh negara. Namun pada kenyataannya, manajemen perusahaan tetap berupaya untuk dapat mencari celah demi pembayaran pajak yang efisien. Kondisi ini menceriminkan bahwa, masih adanya manajemen perusahaan yang berupaya untuk membayar pajak minimal (Kurniasih et al., 2017).

Terdapat beberapa tindakan yang terindikasi sebagai pajak agresif (Atwood et al., 2012). Tindakan itu diantaranya adalah masih adanya perusahaan yang berusaha membayar pajak lebih sedikit dari aturan yang telah diberlakukan. Perusahaan masih ada yang menunda pembayaran pajaknya. Selain itu perusahaan juga berusaha untuk mengenakan pajak dari keuntungan yang seharunya diperoleh (Atwood et al., 2012).

Pajak agresif mencerminkan upaya atau perilaku perusahaan untuk menghindari pembayaran pajak dengan cara-cara yang tidak bertentangan dengan aturan yang telah ditetapkan oleh negara. Pajak agresif ini disatu sisi diperbolehkan, namun disisi yang lain pajak agresif ini tidak dikehendaki oleh menajemen perusahaan. Hal ini karena adanya resiko yang akan dihadapi oleh perusahaan jika keliru dalam perhitungan pajak perusahaan (Rani, Susetyo, \& Fuadah, 2018).

Ada beberapa tindakan manajemen yang mencerminkan perilaku dari penghindaran pajak tersebut. Perusahaan memperkecil jumlah pajak yang seharusnya dibayarkan. Perbandingannya dapat dilihat dari jumlah pajak yang dibayarkan dengan pendapatan perusahaan sebelum dikenakan pajak (Salaudeen, 2017).

Pratiknya di Indonesia, seperti perusahaan Asian Agri. Perusahaan ini menjelankan usahanya dibidang pertanian dan perkebunan. Perusahaan ini pernah mengelapkan pembayaran pajak perusahaan lebih dari 2 trillin rupiah (Panjalusman, Nugraha, \& Setiawan, 2018). Kondisi ini mencerminkan bahwa perusahaan berupaya untuk memperkecil besaran pajak yang seharusnya dibayarkan yaitu dengan cara merendahkan laba perusahaan (Rani et al., 2018).

Berdasarkan fenomena tersebut, menarik untuk diteliti faktor-faktor penentu atau yang mempengaruhi pajak agresif. Tentu tidak mudah untuk mengidentifikasi seluruh faktorfaktor yang mempengaruhi pajak agresif. Berdasarkan survei literatur yang telah dilakukan, tata kelola perusahaan dan pertumbuhan penjualan teridentifikasi sebagai faktor-faktor yang mempengaruhi pajak agresif (Atwood et al., 2012; Braga, 2017; Delgado, Fernandez-Rodriguez, \& Martinez-Arias, 2014; Ermad \& Umar, 2021; Kurniasih et al., 2017; Multazam, 2018; Rani et al., 2018; Sunarsih \& Oktaviani, 2016).

Berdasarkan paparan sebelumnya, maka tertarik untuk dilakukan penelitian dengan judul "Pengaruh Tata Kelola Perusahaan dan Pertumbuhan Penjualan terhadap Pajak Agresif pada Perusahaan Sektor Manufaktur yang Terdaftar di Bursa Efek Indonesia”.

Artikel ini bertujuan menguji pengaruh tata kelola perusahaan dan pertumbuhan penjualan terhadap pajak agresif pada perusahaan sektor 
manufaktur yang terdaftar di Bursa Efek Indonesia. Pembahasan artikel ini dimulai dari pendahuluan, literature review, kemudian dilanjutkan metode penelitian, hasil penelitian dan pembahasan, terakhir adalah kesimpulan.

\section{Tinjauan Literatur}

\section{Hubungan Tata Kelola Perusahaan dengan Pajak Agresif}

Tata kelola perusahaan berkontribusi atas pajak agresif (Kurniasih et al., 2017). Kontribusi tersebut dapat dilihat besar kecilnya kegiatan pajak agresif yang terjadi dalam perusahaan. Tata kelola perusahaan yang ada dalam perusahaan berperan memonitoring perilaku manajemen perusahaan. Tindakan pengawasan tersebut sehubungan dengan adanya perilaku oportunistik direktur perusahaan untuk memaksimumkan kepentingan pribadinya. Kondisi ini akan berdampak terhadap timbulnya keterbatasan manajemen dalam melakukan tindakan penghindaran pajak, sehingga penghindaran pajak akan menurun.

Hasil penelitian terdahulu menemukan bahwa tata kelola perusahaan dapat menurunkan penghindaran pajak. Hal ini karena tindakan manajemen yang dipantau, sehingga mereka tidak dengan mudah untuk mencari peluang melakukan tindakan yang berisiko bagi pemilik perusahaan (Multazam, 2018). Selain itu, adanya juga tindakan pengawasan tersebut sehubungan dengan adanya perilaku oportunistik direktur perusahaan untuk memaksimumkan kepentingan pribadinya (Kurniasih et al., 2017). Kondisi ini akan berdampak terhadap timbulnya keterbatasan manajemen dalam melakukan tindakan pajak agresif.

H1: Tata kelola perusahaan berpengaruh negatif terhadap pajak agresif.

\section{Hubungan Pertumbuhan Penjualan dengan Pajak Agresif}

Pertumbuhan penjualan memiliki hubungan pajak agresif (Rani et al., 2018). Hubungan ini dapat dilihat dari peranan pertumbuhan penjualan atas pajak agresif. Pertumbuhan penjualan merupakan peningkatan penjualan tahun ini yang ditandingkan dengan penjualan tahun sebelumnya (Ermad, 2012). Adanya pertumbuhan penjualan yang terlihat dalam laporan keuangan perusahaan akan mengindikasikan besarnya laba perusahaan. Hal ini berpotensi adanya tindakan pajak agresif yang dilakukan oleh manajemen. Hal ini tentunya akan meningkatkan pajak agresif.

Hal yang relevan juga diungkapkan oleh penelitian terdahulu (Braga, 2017). Mereka mengungkapkan bahwa pertumbuhan penjualan berhubungan positif dengan pajak agresif. Hubungan tersebut terlihat dari pertumbuhan penjualan yang berfungsi sebagai isyarat tumbuhnya suatu perusahaan. Hal ini akan berdampak terhadap peningkatan pajak agresif. Kondisi ini akibat dari akan adanya laba yang besar dari pertumbuhan penjualan tersebut. Oleh karena itu akan meningkatnya pajak agresif.

$\mathrm{H} 2$ : Pertumbuhan penjualan berpengaruh positif terhadap pajak agresif..

\section{Metodologi Penelitian}

Tujuan dari penelitian ini adalah ingin memberikan bukti bahwa bagaimana pengaruh tata kelola perusahaan dan pertumbuhan penjualan dapat berdampak terhadap pajak agresif. Investigasi dalam penelitian ini dilakukan dengan studi kausal. Intervensi dalam penelitian ini adalah intervensi minimal. Begitu juga dengan situasi dalam penelitian ini adalah tidak diatur. Laporan keuangan yang diperoleh akan dianalisis, tanpa ada intervensi terhadap data. Peneliti hanya mengumpulkan data dan selanjutnya menganalisis data tersebut untuk menjawab rumusan masalah dalam penelitian. Yang menjadi unit analisis dalam penelitian ini adalah perusahaan sektor manufaktur. Horizon waktunya adalah data panel seimbang periode pengamatan 2017-2019. Begitu juga dnegan populasi dalam penelitian ini adalah perusahaan manufaktur yang ada di Bursa Efek Indonesia. Penelitian ini mengati semua populasi yang berjumlah 111 perusahaan. Selanjutnya pengukuran variabel dalam penelitian ini yaitu tata kelola perusahaan diukur dengan indeks dari jumlah dewan direksi dan jumlah komite audit (Multazam, 2018). Pertumbuhan penjualan diukur dengan skala rasio dari penjualan tahun ini dikurangi dengan penjualan tahun lalu kemudian ditandingkan dengan 
penjualan tahun lalu (Ermad, 2012). Selanjutnya pajak agresif mengikuti diukur dengan skala rasio dari penandingan dari jumlah pajak yang dibayarkan dengan pendapatan sebelum pajak (Sunarsih \& Oktaviani, 2016).

Pemakaian data dalam penelitian ini adalah berupa data sekunder. Data tersebut yaitu laporan keuangan dari masing-masing perusahaan yang menjadi pengamatan. Data diperoleh dengan cara mengunduh langsung pada situs resmi BEI. Kemudian, juga mengecek pada situs resmi masing-masing perusahaan. Data yang dipakai adalah data panel seimbang, kemudian dianalisis denagan metode Panel Least Squares (PLS) dan dengan uji Common Effect Models (CEM) dengan bantuan aplikasi eviews.

\section{Hasil dan Pembahasan}

\section{Statistik Deskriptif}

Tabel 1. Statistik Deskriptif

\begin{tabular}{|l|l|c|c|c|}
\hline \multicolumn{2}{|l|}{} & $\begin{array}{c}\text { Pertumbuhan } \\
\text { Penjualan }\end{array}$ & Tata Kelola & $\begin{array}{c}\text { Pajak } \\
\text { Agresif }\end{array}$ \\
\hline \multirow{2}{*}{ N } & Valid & 111 & 111 & 111 \\
\cline { 2 - 5 } & Missing & 0 & 0 & 0 \\
\hline \multicolumn{2}{|l|}{ Mean } & 0.0540 & 0.1183 & 0.2654 \\
\hline \multicolumn{2}{|l|}{ Minimum } & 0.0396 & 0.0008 & 0.0411 \\
\hline \multicolumn{2}{|l}{ Maximum } & 0.0758 & 0.5399 & 0.6567 \\
\hline
\end{tabular}

Berdasarkan Tabel 1 terlihat nilai rata-rata, minimum dan maksimum untuk masingmasing variabel penelitian. Nilai rata-rata pertumbuhan penjualan yang itu sebesar 0,054 . Hal ini menunjukan bahwa selam periode pengamatan, perusahaan memiliki pertumbuhan perusahaan sebesar $54 \%$ dari tahun sebelumnya. Kemudian nilai rata-rata tata kelola perusahaan sebesar 0,1183. Hal ini menunjukan bahwa indeks tata kelola perusahaan yang menjadi pengamatan. Selanjutnya pajak agresif memiliki nilai sebesar 0,2654 . Nilai ini menunjukan bahwa, selama periode pengamatan, perusahaan rata-rata melakukan pembayaran pajak sebesar 26,54\% dari pendapatan perusahaan.

\section{Hasil Pengujian Hipotesis}

Berikut ini akan diperlihatkan hasil pengujian hipotesis. Secara ringkas dapat dilihat pada Tabel 2.

Tabel 2. Hasil Pengujian Hipotesis

\begin{tabular}{|c|c|c|c|c|}
\hline \multicolumn{2}{|l|}{ Effects Test } & Statistic & d.f. & Prob. \\
\hline \multicolumn{2}{|l|}{ Cross-section F } & 0.833664 & $(36,72)$ & 0.7218 \\
\hline \multicolumn{2}{|c|}{ Cross-section Chi-square } & 38.674979 & 36 & 0.3498 \\
\hline \multirow{2}{*}{\multicolumn{5}{|c|}{$\begin{array}{l}\text { Cross-section fixed effects test equation: } \\
\text { Dependent Variable: } Y\end{array}$}} \\
\hline & & & & \\
\hline \multicolumn{5}{|c|}{ Date: $10 / 26 / 21$ Time: $12: 08$} \\
\hline \multicolumn{5}{|l|}{ Sample: 20172019} \\
\hline \multicolumn{5}{|c|}{ Periods included: 3} \\
\hline \multirow{2}{*}{\multicolumn{5}{|c|}{$\begin{array}{l}\text { Cross-sections included: } 37 \\
\text { Total panel (balanced) observations: } 111\end{array}$}} \\
\hline & & & & \\
\hline Variable & Coefficient & Std. Error & t-Statistic & Prob. \\
\hline c & 0.276714 & 0.048119 & 5.750625 & 0.0000 \\
\hline $\mathrm{x} 1$ & -0.058126 & 0.072355 & -0.803348 & 0.4235 \\
\hline X2 & 0.080409 & 0.843687 & 0.095307 & 0.9242 \\
\hline R-squared & 0.005942 & \multicolumn{2}{|c|}{ Mean dependent var } & 0.265487 \\
\hline Adjusted R-squared & -0.012467 & \multirow{2}{*}{\multicolumn{2}{|c|}{$\begin{array}{l}\text { S.D. dependent var } \\
\text { Akaike info criterion }\end{array}$}} & 0.079688 \\
\hline S.E. of regression & 0.080183 & & & -2.182345 \\
\hline Sum squared resid & 0.694373 & \multicolumn{2}{|c|}{ Schwarz criterion } & -2.109114 \\
\hline Log likelihood & 124.1201 & \multirow{2}{*}{\multicolumn{2}{|c|}{$\begin{array}{l}\text { Hannan-Quinn criter. } \\
\text { Durbin-Watson stat }\end{array}$}} & -2.152637 \\
\hline F-statistic & 0.322760 & & & 1.931534 \\
\hline Prob(F-statistic) & 0.724844 & & & \\
\hline
\end{tabular}

\section{Pengaruh Tata Kelola Perusahaan terhadap Pajak Agresif}

Berdasarkan Tabel 2, terlihat nilai coefficient tata telola perusahaan $\left(\mathrm{X}_{1}\right)$ sebesar $-0,0581$. Nilai ini tidak sama dengan nol $(-0,0581 \neq 0)$. Artinya bahwa tata kelola perusahaan berpengaruh terhadap pajak agresif. Selanjutnya tanda negatif menunjukan arah dari pengaruhnya. Hal ini berarti tata kelola perusahaan berpengaruh menurunkan pajak agresif.

Hasil penelitian relevan penelitian terdahulu (Multazam, 2018; Sunarsih \& Oktaviani, 2016). Mereka menemukan bahwa tata kelola perusahaan dapat menurunkan pajak agresif. Tata kelola perusahaan berkontribusi pada pajak agresif. Kontribusi tersebut dapat dilihat besar kecilnya penghindaran pajak yang terjadi dalam perusahan. Tata kelola perusahaan yang ada dalam perusahaan berperan memonitoring dan memantau perilaku para manajemen perusahaan. Tindakan pengawasan tersebut sehubungan dengan adanya perilaku menceri celah oleh direktur perusahaan untuk memaksimumkan kepentingan pribadinya. Kondisi ini akan berdampak terhadap timbulnya keterbatasan manajemen dalam melakukan tindakan penghindaran pajak, sehingga pajak agresif akan menurun. 


\section{Pengaruh Pertumbuhan Penjualan terhadap Pajak Agresif}

Berdasarkan Tabel 2, terlihat nilai coefficient pertumbuhan penjualan $\left(\mathrm{X}_{2}\right)$ sebesar $-0,0804$. Nilai ini tidak sama dengan nol $(-0,0804 \neq 0)$. Artinya bahwa pertumbuhan penjualan berpengaruh terhadap pajak agresif. Selanjutnya tanda negatif menunjukan arah dari pengaruhnya. Hal ini berarti pertumbuhan penjualan berpengaruh menurunkan pajak agresif. Hasil penelitian ini berbeda dengan penelitian terdahulu (Braga, 2017; Kurniasih et al., 2017; Rani et al., 2018). Mereka menyatakan bahwa pertumbuhan penjualan akan meningkatkan pajak agresif. Namun hasil penelitian ini menemukan akan menurunkan pajak agresif. Pertumbuhan penjualan merupakan peningkatan penjualan tahun ini yang ditandingkan dengan penjualan tahun sebelumnya. Adanya pertumbuhan penjualan yang terlihat dalam laporan keuangan perusahaan akan mengindikasikan besarnya laba perusahaan. Hal ini akan membuat manajemen perusahaan untuk membayar pajak dan berpotensi kecil untuk menghidari pajak. Hal ini menunjukan akan menurunnya pajak agresif.

\section{Kesimpulan}

Kesimpulan yang dapat diberikan dari penelitian ini adalah tata kelola perusahaan dan pertumbuhan penjualan berpengaruh menurunkan pajak agresif. Adanya tata kelola perusahaan dan pertumbuhaan penjualan menjadikan perusahaan menurun dalam bertindak pada pajak agresif. Saran untuk perusahaan yang menjadi pengamatan akan tetap mempertahankan tata kelola perusahaan dan pertumbuhan penjualan. Kemudian untuk penelitian selanjutnya agar memperluas topik terperinci pada proski lainnya untuk masingmasing variabel.

\section{Daftar Pustaka}

Atwood, T. J., Drake, M. S., Myers, J. N., \& Myers, L. A. (2012). Home country tax system characteristics and corporate tax avoidance: International evidence. Accounting Review, 87(6), 1831-1860. https://doi.org/10.2308/accr-50222
Braga, R. N. (2017). Effects of IFRS adoption on tax avoidance. Revista Contabilidade E Financas, 28(75), 407-424. https://doi.org/10.1590/1808057x201704680

Delgado, F. J., Fernandez-Rodriguez, E., \& Martinez-Arias, A. (2014). Effective tax rates in corporate taxation: A quantile regression for the EU. Engineering Economics, 25(5), 487-496. https://doi.org/10.5755/j01.ee.25.5.4531

Ermad, E. (2012). Pengaruh Tangibility, Pertumbuban Penjualan, Profitabilitas, dan Kepemilikan Institusional terhadap Struktur Modal pada Perusabaan Industri Dasar dan Kimia yang terdaftar di Bursa Efek Indonesia (Phdthesis). Tesis. Banda Aceh: Program Studi Magister Akuntansi Program Pasca Sarjana.

Ermad, E., \& Umar, Z. (2021). BISMA Cendekia Impact of Corporate Governance, Financial Leverage, and Sales Growth on Tax Avoidance of Manufacturing Sector Companies Listed on the Indonesia Stock Exchange. 1(2), 6-13.

Kurniasih, L., Sulardi, \& Suranta, S. (2017). Earnings management, corporate governance and Tax Avoidance: The case in Indonesia. Journal of Finance and Banking Review, 2(4), 28-35. https://doi.org/10.1166/asl.2016.8147

Multazam, S. \& R. (2018). the Influence of Leverage , Executive Incentives, Managerial Ownership on Tax Aggressiveness ( Study in Manufacturing Companies Listed on Idx Year 2012-2014 ). Jurnal Ilmiah Mahasiswa Ekonomi Akuntansikuntansi, 3(3), 494-504.

Panjalusman, P. A., Nugraha, E., \& Setiawan, A. (2018). Pengaruh Transfer Pricing Terhadap Penghindaran Pajak. Jurnal Pendidikan Akuntansi \& Keuangan, 6(2), 105. https://doi.org/10.17509/jpak.v6i2.1591 6 
Rani, S., Susetyo, D., \& Fuadah, L. L. (2018). The effects of the corporate's characteristics on tax avoidance moderated by earnings management (Indonesian evidence). Journal of Accounting, Finance and Auditing Studies, 4(3), 149-169.

Salaudeen, Y. M. (2017). Corporate Effective Tax Rates in the Financial Services Sector: Evidence from Nigeria. International Journal of Accounting and Taxation, 5(1), 68-88. https://doi.org/10.15640/ijat.v5n1a6
Sunarsih, U., \& Oktaviani, K. (2016). Good Corporate Governance in Manufacturing Companies Tax Avoidance. Etikonomi, 15(2),

85-96. https://doi.org/10.15408/etk.v15i2.3541. 